\title{
Effects of Fenugreek Seed (Trigonella foenum - graecum) and Coriander Leaf (Coriandrum sativum) as Feed Additives on the Growth Performance and Carcass Characteristics of Weaned Rabbits
}

\author{
Adejola Y.A Olanrewaju A Akinbola D.D Apiakason E Fagbemi D.O \\ Department of Animal Production Technology, Federal College of Agriculture, P.M.B. 5029, Moor Plantation, \\ Ibadan, Nigeria
}

\begin{abstract}
A 35 day study was conducted to carry out effect of fenugreek seed and coriander leaf as feed additives on growth performance and carcass characteristics of weaned rabbits. Thirty six unsexed weaned rabbits were randomly assigned to four treatments; each treatment comprised of three replicates with three rabbits each. Treatment 1 contained basal diet with no feed additive which served as the control, treatment 2 were served basal diet plus $250 \mathrm{~g}$ fenugreek seed powder, treatment 3 were served basal diet plus $250 \mathrm{~g}$ coriander leaf powder and treatment 4 were served basal diet plus a mixture of $125 \mathrm{~g}$ fenugreek seed powder and $125 \mathrm{~g}$ coriander leaf powder. Data were collected on growth performance and carcass characteristics and were subjected to analysis of variance (ANOVA) in a completely randomized design. Significant differences $(p<0.05)$ were observed in the growth performance parameters in which treatment 2 had the highest average weight gain performance value of $(416.00 \mathrm{~g})$, followed by treatment $4(316.17 \mathrm{~g})$, treatment $1(313.83 \mathrm{~g})$, while treatment 3 had the lowest weight gain $(263.17 \mathrm{~g})$. No significant differences $(p<0.05)$ were observed in all carcass characteristics parameters. From the result of this study, it can be concluded that fenugreek seed powder added at the dosage of $250 \mathrm{~g}$ improved the growth performance of the weaned rabbits.
\end{abstract}

Keywords: Carcass characteristics, Coriander Leaf powder, Fenugreek seed Powder, Growth performance and Weaned rabbits

DOI: $10.7176 / \mathrm{JBAH} / 9-12-07$

Publication date:June $30^{\text {th }} 2019$

\section{INTRODUCTION}

Antimicrobial compounds are commonly included in Rabbitary diets for promoting of growth and control of diseases. The European Union banned feed antibiotic growth promoters, due to, not only cross- resistance, but also to the risk of possible drugs multiple resistances in human pathogenic bacteria. Feeds containing no chemical additives are increasingly used in rabbitary nutrition. Consequently, the animal feed manufacturers are exposed to increasing consumer pressure to reduce the use of antibiotic growth promoters as feed additive and fend alternatives to antibiotic growth promoters in Rabbitary diets (Humphrey, 2002).

Many scientists searched for alternatives to antibiotics growth promoter (Kamel, 2001). The feed manufacturers are adopting new forms of natural feed additives that are the product of modern science (Wezyk and Poltowicz, 2000). Therefore, the effects expected of herbs and plant extracts are also various: the herbs and plant extracts act on the appetite and intestinal, microflora, stimulate the pancreatic secretions to increase endogenous enzyme activity and immune system. Many plant products and their constituents have a broad antimicrobial activities antioxidant and sedative properties. Besides, scientists recently discovered that the appetizing and stimulating activity of herbs and plant extracts on animal digestive and immune system could benefit performance and health of farm animal (Tucker, 2002).

Fenugreek (Trigonella foenum graecum) is grown mainly in India, Pakistan and China. Its seed have mainly therapeutical effects such as hypoglycemic, anti- helminthic, anti-inflammatory and anti -microbial properties (Bash et al., 2003). It also contains lecithin and chlorine that help to dissolve cholesterol and fatty substances. It also contains neurin, biotin, trimethylamine which tends to stimulate the appetite by their action on the nervous system (Micheal and Kumawat, 2003). Fenugreek leaves and seeds have been used extensively to prepare extracts and powders for medicinal used (Smith, 2003).

Coriander (Coriandrum sativum) is an aromatic plant, is an annual species of the parlsey family, native to the eastern Mediterranean region and southern Europe, and is found in many other parts of the world. As a medicinal plants, Coriander (Coriandrum sativum) has been used as antimicrobial (Singh et al., 2002) hypocholesterolemic (Chithara and Leelama, 1999) substance. In addition, it has appetizing and stimulatory effects in the digestion process (Cabuk et al., 2003).

Based on the aforementioned properties, a research study was conducted to explore the potential of combining Fenugreek seed meal and Coriander leaf meal as natural feed additives in the diets of weaned rabbits. 


\section{MATERIALS AND METHODS \\ EXPERIMENTAL SITE}

The experiment was carried out at the livestock unit of the Federal college of Agriculture Moor Plantation, Ibadan, Nigeria.

\section{DURATION OF EXPERIMENT}

The experiment lasted for 5 weeks (35 days)

\section{SOURCE AND PROCESSING OF TEST INGREDIENTS}

Dried fenugreek seeds and coriander leaves were purchased from a market in Ibadan and both were milled together to obtain product herein refers to as fenugreek seed powder (FSP) and coriander leaves Powder (CLP) all the test ingredients were stored in sacs until they were needed.

\section{EXPERIMENTAL DIET AND MANAGEMENT}

Table 1 presents the ingredients composition of the weaned rabbit diets according to the experimental design. All rabbits were reared in hutches and were thoroughly cleared. Access to feed and water was provided and good hygiene was also maintained during the study.

\section{EXPERIMENTAL RABBITS AND DESIGN}

Thirty-six unsexed rabbits were purchased from a reputable farm at Ibadan. The rabbits were acclimatized for a week and later randomly assigned to four (4) treatments; each treatment comprised three (3) replicates with 3 rabbits each. All rabbit were rear in hutches and the hutches were properly cleaned. The rabbit were provided with clean water ad-libitum while feed were served twice daily by $08.00 \mathrm{hr}$ and $16.00 \mathrm{hr}$. Feed offered and the left-over feed were weighed to determine the feed intake of the animal, after the initial weight, weekly weight were taken, this record were used to determine the performance parameter. Good hygiene was also maintained during the study. The groups were allocated as follows:

$\mathrm{T}_{1}(\mathrm{control})=$ basal diet with no feed additive.

$\mathrm{T}_{2}=$ basal diet plus $250 \mathrm{~g}$ fenugreek seed powder

$\mathrm{T}_{3}=$ basal diet plus $250 \mathrm{~g}$ coriander leaf powder

$\mathrm{T}_{4}=$ basal diet plus a mixture of $125 \mathrm{~g}$ fenugreek seed powder and $125 \mathrm{~g}$ coriander leaf powder.

\section{DATA COLLECTION}

\section{PERFORMANCE CHARACTERISTICS}

Data on the feed and water intake were taken on daily basis. Daily feed intake was used to work out weekly feed intake. Feed intake was calculated by feed offered - feed refused and water was given to them ad -libitum.

Weekly weight gain was calculated by subtracting initial weight from final weight of each week and weekly FCR was calculated by dividing weekly feed consumed by weekly weight gain.

Average Weight Gain $(\mathrm{g})$ = Final weight - Initial weight $(\mathrm{g} / \mathrm{rabbit} /$ day $)$;

Feed intake $(\mathrm{g})=$ Feed given - Feed left $(\mathrm{g} / \mathrm{rabbit} / \mathrm{day})$;

Feed Conversion Ratio $=$ Feed Intake

\section{Weight gain}

\section{CARCASS CHARACTERISTICS}

At the end of the experiment, one rabbit from each treatment were randomly selected such that their weights were similar to the mean weight of each replicate for the evaluation of carcass characteristics. Prior to slaughtering, the rabbits were made to fast but given water in order to flush the gut tract and live weight of each selected rabbit was taken. Each rabbit were skinned and eviscerated for organs weight (heart, liver, kidney, lungs, spleen, full intestine) and a standard cut of fore limb, hind limb, head for carcass evaluation.

\section{STATISTICAL ANALYSIS}

The experimental design was a Completely Randomized Design (CRD) and data obtained were subjected to oneway Analysis of Variance using SAS (1999).

Significant $(\mathrm{P}<0.05)$ means among variables were separated using Duncan Multiple Range Test as contained in the SAS (1999) package.

Experimental model;

$\begin{array}{lll}\mathrm{Y}_{\mathrm{ij}} & = & \mu+\mathrm{T}_{\mathrm{i}}+\sum_{\mathrm{ij}} \\ \mu & = & \text { Population mean } \\ \mathrm{T}_{\mathrm{i}} & = & \text { Effect of dietary treatments } \\ \sum_{\mathrm{ij}} & = & \text { residual error }\end{array}$


Table 1: Gross Composition of Experimental Diets

\begin{tabular}{lc}
\hline Ingredients & Composition $(\mathrm{Kg})$ \\
\hline Maize & 40.00 \\
Soyabean meal & 6.00 \\
Groundnut cake & 5.00 \\
Wheat offal & 44.00 \\
Bone meal & 2.00 \\
Limestone & 2.00 \\
Lysine & 0.25 \\
Methionine & 0.25 \\
Premix & 0.25 \\
Salt & 0.25 \\
Total & 100.00 \\
\hline Calculated Chemical Composition & \\
Crude Protein (\%) & 16.00 \\
Metabolisable Energy (kcal/kg) & 2483.60 \\
Crude fibre (\%) & 5.20 \\
Ether extract $(\%)$ & 3.66 \\
Calcium (\%) & 1.23 \\
Phosphorus (\%) & 0.38
\end{tabular}

\section{RESULT}

Table 2: Effect of Fenugreek Seed Powder and Coriander Leaf Powder on the Growth Performance of Weaned Rabbits

\begin{tabular}{|c|c|c|c|c|c|}
\hline Parameters & $\mathrm{T}_{1}$ & $\mathrm{~T}_{2}$ & $\mathrm{~T}_{3}$ & $\mathrm{~T}_{4}$ & SEM \\
\hline Initial weight (g) & 590.50 & 586.67 & 590.17 & 588.20 & 49.27 \\
\hline Final weight (g) & 904.33 & 1002.67 & 853.34 & 904.37 & 114.31 \\
\hline TFI $(g)$ & $987.77^{\mathrm{b}}$ & $1004.50^{\mathrm{a}}$ & $1000.90^{\mathrm{a}}$ & $1005.30^{\mathrm{a}}$ & 2.38 \\
\hline Weight gain $(\mathrm{g})$ & $313.83^{b}$ & $416.00^{\mathrm{a}}$ & $263.17^{\mathrm{c}}$ & $316.17^{\mathrm{b}}$ & 7.63 \\
\hline $\operatorname{ADWG}(\mathrm{g})$ & $8.97^{b}$ & $11.89^{\mathrm{a}}$ & $7.52^{\mathrm{c}}$ & $9.03^{\mathrm{b}}$ & 0.22 \\
\hline $\mathrm{ADFI}(\mathrm{g})$ & $28.22^{\mathrm{b}}$ & $28.70^{\mathrm{a}}$ & $28.60^{\mathrm{a}}$ & $28.72^{\mathrm{a}}$ & 0.07 \\
\hline FCR & $3.15^{\mathrm{b}}$ & $2.41^{\mathrm{c}}$ & $3.83^{\mathrm{a}}$ & $3.18^{\mathrm{b}}$ & 0.09 \\
\hline
\end{tabular}

a,b,c Means with different superscript on the same row differ significantly different $(\mathrm{p}<0.05)$

TFI $=$ Total Feed Intake,

ADWG = Average Daily Weight Gain

ADFI $=$ Average Daily Feed Intake

FCR $=$ Feed Conversion Ratio

Table 3: Effect of Fenugreek Seed Powder and Coriander Leaf Powder on Carcass Characteristics of Weaned Rabbits

\begin{tabular}{llllll}
\hline Parameters & $\mathrm{T}_{1}$ & $\mathrm{~T}_{2}$ & $\mathrm{~T}_{3}$ & $\mathrm{~T}_{4}$ & $\mathrm{SEM}$ \\
\hline FLW $(\mathrm{g})$ & 939.00 & 867.00 & 800.00 & 823.00 & 97.05 \\
DW(\%) & 52.04 & 47.66 & 50.64 & 50.37 & 3.33 \\
Head(\%) & 9.86 & 10.49 & 9.91 & 9.62 & 0.85 \\
Forelimb(\%) & 6.07 & 6.08 & 6.08 & 6.43 & 0.47 \\
Hind limb (\%) & 12.50 & 11.47 & 12.11 & 11.75 & 1.03 \\
Liver(\%) & 2.51 & 2.44 & 2.51 & 2.57 & 0.16 \\
Lungs(\%) & 0.83 & 1.04 & 1.14 & 0.98 & 0.15 \\
Spleen (\%) & 0.14 & 0.12 & 0.12 & 0.12 & 0.02 \\
Kidney (\%) & 0.71 & 0.58 & 0.79 & 0.84 & 0.13 \\
Hearth (\%) & 0.39 & 0.35 & 0.38 & 0.25 & 0.05 \\
Full Intestine (\%) & 19.03 & 20.51 & 19.50 & 20.80 & 1.47 \\
\hline
\end{tabular}

FLW $=$ Final Live Weight

DW $=$ Dressed Weight

\section{DISCUSSION}

Table 2 shows effects of FSP and CLP on the growth performance of weaned rabbit. Although, there were no significant difference $(p>0.05)$ for initial and final weight across the treatments but it was observed that $T_{2}$ had the 
highest weight gain $(416.00 \mathrm{~g})$ which suggests to their high feed intake and phytogenic attributes and the value is highly significantly different $(\mathrm{p}<0.05)$ to $\mathrm{T}_{1}(313.83 \mathrm{~g}), \mathrm{T}_{4}(316.17 \mathrm{~g})$ and $\mathrm{T}_{3}(263.17 \mathrm{~g})$. The result of this study is similar to the study of Zeweil, 2015, who observed an improvement of body weight gain of rabbits fed fenugreek based diet which he said might be attributed to the active compounds such as antibacterial, antifungal, antiinflammatory and antioxidant properties of fenugreek seed powder.

However, total feed intake parameters had significant difference $(\mathrm{p}<0.05)$ across the treatments. $\mathrm{T}_{2}(1004.5 \mathrm{~g})$, $\mathrm{T}_{3}(1000.9 \mathrm{~g})$ and $\mathrm{T}_{4}(1005.3 \mathrm{~g})$ were significantly different $(\mathrm{p}<0.05)$ to $\mathrm{T}_{1}(987.77 \mathrm{~g})$ which had the lowest feed intake being the control experiment. This correlates to the report of Hernandez et al., 2004 who reported that the improvement due to fenugreek seed has stimulating effect of the digestive system. This also agrees with Micheal and Kumawat, 2003 and Alloui et al., 2012 who reported that fenugreek seed also contain neurons, biotin, trimthylamine which tends to stimulate the appetite by their action on the nervous system. The FCR was significantly different $(p<0.05)$ across the treatments but was it was lowest in $T_{2}(2.41)$ which implies that the rabbits on $\mathrm{T}_{2}$ had the best feed conversion to meat.

Table 3 shows the effect of FSP and CLP on the carcass characteristics of weaned rabbits. The values for carcass characteristics were not significantly different ( $\mathrm{p}>0.05)$ across the treatment FSP based diet had the lowest values for dressing percentage (47.66\%), hind limb (11.47\%), liver $(2.44 \%)$, spleen $(0.12 \%)$ and kidney $(0.58 \%)$. The value for the dressing percentage for this study is in contrast with that reported by Alloui et al., 2012 who reported an increase in dressing percentage of rabbit feed fed with fenugreek seed powder. However, it was observed that rabbits on fenugreek based on diet had the highest value for head weight percentage $(10.49 \%)$ as compared to other diets.

\section{CONCLUSION}

From the result of this study, it can be concluded that:

Fenugreek seed powder based diet improved the growth performance of weaned rabbits at $250 \mathrm{~g}$ but showed little or no effect on carcass characteristics. Coriander leaf powder based diet had less effect on growth performance and carcass characteristics of rabbits at $250 \mathrm{~g}$.

\section{REFERENCES}

Alloui, M.N. (2012). Utilization of fenugreek (Trigonella foenum-graceum) as growth promoter for broiler chickens. Journal of world poultry. 2:25-27.

Bash, E., Ulbricht, C., Kuo,G., Szapany, P. and smith M. (2003). Therapeutic applications of Fengugreek. Alt.med.Rev.8, 2027.

Cabuk, M,A, Alcicek M 2003 .Antionicrobial Properties of the essential oil isolated from arcomatic plants proceeding of the $2^{\text {nd }}$ National Anim. Nutr. Congress, Sept .18-20,2003, Konga, Turkey Pps 184-187.

Chithera. and S. Leelama, 1999. Hypolipidermic effect of corlander seed. Antioxidany enzyme in experimental animlas. Ind. J. Biochemistry. Biophysics., 36:59-61.

Hernandez, F., J.Madrid, V.Garcia,J. Orengo and M.D. Megias,2004. Influence of two plant extracts on broilers performance, digestibility, and digestive organ size. Poultry Science 83:169-174

Humphrey J.B.D 2002 Alternative antibacterial Performances, Promoters, Poult.Int 40,50-52, Nutri 1323,1214128.

Kamel, C,2001 : Trancing modes of action and roles of plant extracts . pp.13 5-150. Recent advances in animal Nutrition

Micheal,D. D.Kumawat 2003. Legend and archeology of fenugreek, constituions of modern applications of fenugreek seeds. International Symposium, USA; Pp: 41-42

Singh.G.I.P.S. Kapoor, K. Mohammed 2000, 2002. studies on essential oils: Part 10 antibacterial activity of volatile oils of some spices phytotherapy. Res., 16:680 - 682

Smith .R.K 2003. The effect of some alternative feed additives for antibiotic growth promoters on the performances . Vet. Animal Sci, 27:727 - 723.

Tucker, L.A 2002b: Plant extract to maintain livestock performances. Feed int 23 (9), 26 - 29.

Wexyk, S,K. and Poltowicz 2000: Effects of replacing antibiotic growth stimulants with herbs on performance World Livestock. Cong., 20 -24 August., 2000, Montreal, Canada

Zeweil, H.S., El- Nagar, S., Zahran, S.M., Ahmed, M.H., El- Gindy, Y.,2013. Pomogranate Peel as a Natural Antioxidant Boost Buck's Fertility Under Egyptian Summer Conditions World Rabbit Sci.2013,21:33-39. 